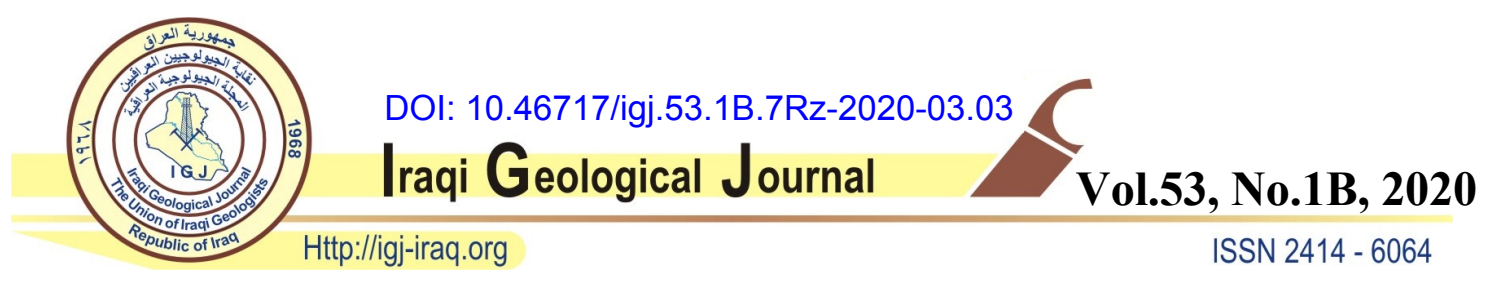

\title{
ASSESSMENT OF DRINKING WATER QUALITY AND SANITATION IN AJDABIYA CITY, NE LIBYA
}

\author{
${ }^{1}$ Osama R. Shaltami ${ }^{*}{ }^{2}$ Fares F. Fares, ${ }^{3}$ Saad M.El-Shari, ${ }^{4}$ Farag, M. EL Oshebi, ${ }^{5}$ Fathi M. \\ Salloum, ${ }^{6}$ Rachelle R. Favaloro, ${ }^{7}$ Nessma Alshelmani, ${ }^{8}$ Abdulrahman Al-Maqrif and ${ }^{9}$ Souad A. Moftah \\ 1,3,4,5,8 Department of Earth Sciences, Faculty of Science, Benghazi University \\ ${ }^{2}$ Department of Petroleum Engineering, Faculty of Engineering, Libyan British University \\ ${ }^{6}$ Independent researcher, USA \\ ${ }^{7}$ Department of Chemistry, Faculty of Science, Benghazi University \\ ${ }^{9}$ Department of Zoology, Faculty of Art and Science, Benghazi University \\ *E-mail: Osam.Rahil@yahoo.com
}

Received: 1 October 2019; accepted: 27 December 2019

\begin{abstract}
The main objective of this work is to assess the drinking water quality and sanitation in Ajdabiya city. Five water samples were collected from Ajdabiya reservoir and household wells, the chemical analysis data shows the studied water must be treated to remove the contaminations according to WHO (2018). Most of the sewage water of Ajdabiya city flows into the ground and the sabkha lakes without any treatment, which leads to contamination of groundwater because of the lack of a sewage network.
\end{abstract}

Keywords: Water quality; Sanitation; Ajdabiya city; Libya

\section{INTRODUCTION}

The danger of pollution of underground water depends on the type and concentration rate of the pollutants in it (Al Qawati et al., 2018). The polluted surface water may be absorbed by or penetrated through the soil into the water table (Shaltami et al., 2017). Water resources in Ajdabiya confront several quantity problems such as scarcity of pure water, and quality problems like a chemically polluted, biologically polluted or physically polluted water source, especially in areas with more human activities or those near to water sanitary outlets. (Kourgialas et al., 2017) the degradation of soil and groundwater quality is due to the mismanagement of irrigation water and agrochemical inputs. (Fig. 1 A-B) shows the location map of Libya and the geological map of Ajdabiya city. There are two main water sources, namely Ajdabiya reservoir and household wells (Fig.1B). Alkasih et al. (2017) studied the groundwater quality in Ajdabiya city. They found that unsuitable for drinking. The exposed rock units in the study area and surrounding are composed of Middle Miocene to Quaternary deposits (Giglia G., 1984). The oldest rock unit exposed around 
Ajdabiya City is Qarat Weddah Formation of the Pleistocene age (Fig.1B). It is represented by quartz sands with calcareous sandstone and calcarenite with thin gypsum beds. This unit is overlying by Ajdabiya Formation of Pleistocene -Holocene age. Ajdabiya Formation contains mainly layers of detrital skeletal and calcarenite limestone. The other rock unit exposed in the study area is the Gargarish Formation of also Pleistocene-Holocene age. It is composed of calcarenite and oolitic detrital limestone. All these units are mainly covered by sabkha and eolian sediments. The main objectives of this work are comparing the drinking water samples analysis results with the international quality standers of (2018, WHO) guide line, making the local people aware of the health risk from drinking water and evaluating the sewage network in Ajdabiya city.

\section{METHODOLOGY}

Five samples were collected from studied water during September 2018 (Fig.1B). Two samples from the Ajdabiya reservoir and three samples from household wells. The houses in Ajdabiya city are lacking modern sanitation systems.

$\mathrm{Na}, \mathrm{K}$, and $\mathrm{Cl}$ were carried out using a Flame photometer. $\mathrm{NO}_{3}$ was determined by the spectrophotometer. Heavy metals were analyzed by using AAS Hitachi-3. The analyses were done in the Chemistry Department, Faculty of Science, Benghazi University.

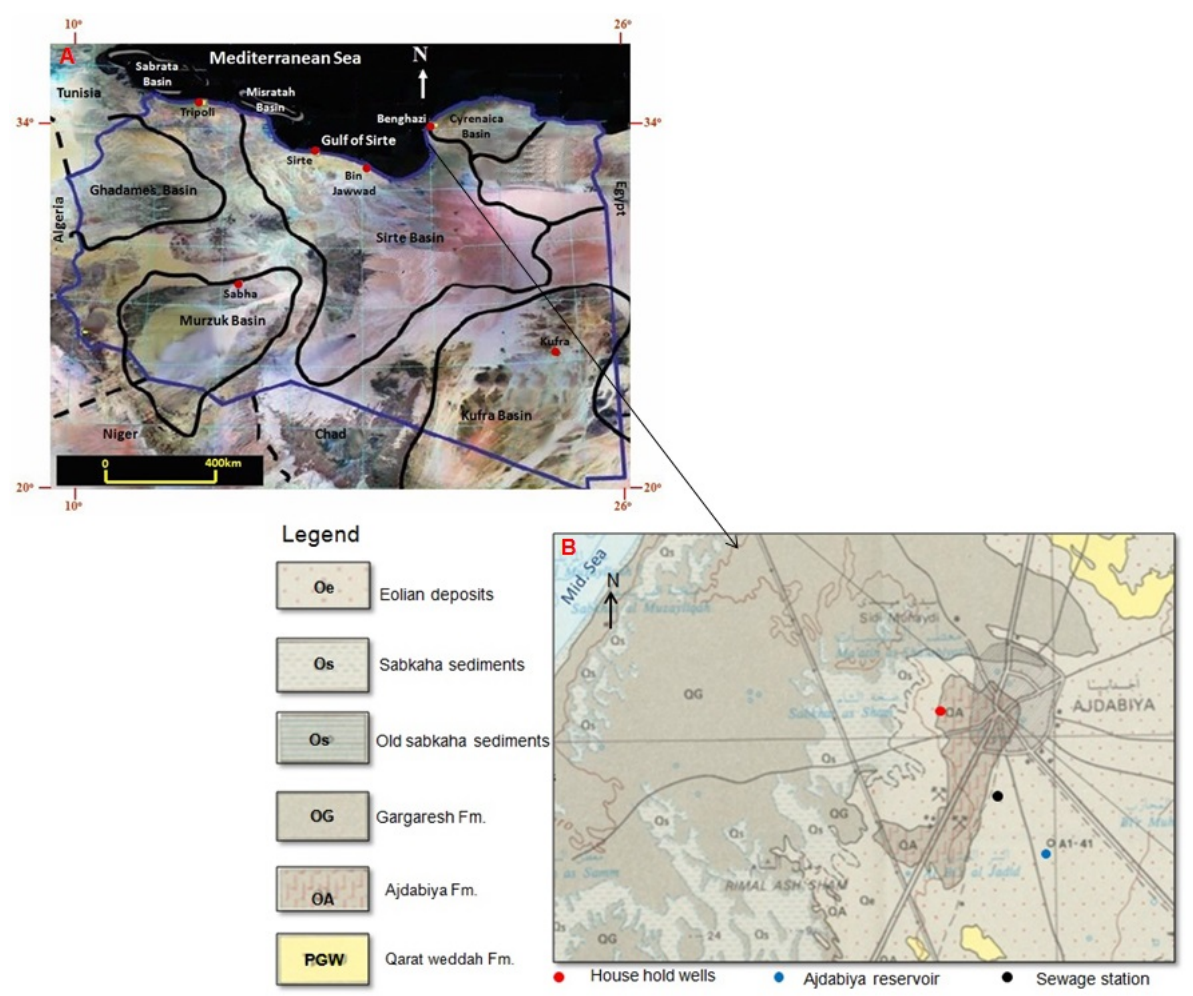

Fig.1: (A) Location map of Libya (Shaltami, 2012) and (B) Geological map of the study area

(Giglia G., 1984) 


\section{RESULTS AND DISCUSSION}

The following is a comparison between the chemical analysis results of the studied water samples and the WHO (2018) values.

1- The contaminate value (except $\mathrm{Pb}$ ) in the Ajdabiya reservoir is below the permissible limit WHO (2018) indicating that this water needs to be treated before use in drinking.

2- In general, the water of household wells are more polluted than Ajdabiya reservoir (Table 1), because it contains high concentrations of $\mathrm{NO}_{3}, \mathrm{Na}, \mathrm{Cl}$ and $\mathrm{Pd}$ in samples 1and 2, while in sample 3 only $\mathrm{Pd}$, therefore the groundwater of Ajdabiya city is polluted with sanitation, so we do not recommend this water for drinking or other uses.

\section{Metal Index}

We use the metal index of the water samples to determine the level of heavy metal contaminations in order to evaluate the suitability of water quality for drinking. According to (Caerio et al., 2005) the $\mathrm{MI}$ is calculated as $\mathrm{MI}=\mathrm{C} / \mathrm{MAC}$, Where $\mathrm{C}$ is the metal concentration $(\mathrm{mg} / \mathrm{l})$ in the water sample and MAC (mg/l) is the maximum allowable concentration (WHO, 2011). MI is classified into six (6) classes: class 1 , very pure $<0.3$; class II, pure $0.3-1$; class III, slightly affected 1-2; class IV, moderately affected 2-4; class V, strongly affected 4-6 and class VI, seriously affected $>6$ (Caerio et al., 2005). The metal index values suggest that the studied water samples in the Ajdabiya reservoir are classified as (class IV) moderately affected while household wells are classified as (class VI) seriously affected.

Table 1: Comparison between the chemical analysis data of the studied water and permissible limits of WHO (2018) in drinking water

\begin{tabular}{|c|c|c|c|c|c|c|}
\hline \multicolumn{3}{|c|}{ Ajdabiya Reservoir } & \multicolumn{4}{c|}{ Househeld Wells } \\
\hline Parameters & $\mathbf{1}$ & $\mathbf{2}$ & $\mathbf{1}$ & $\mathbf{2}$ & $\mathbf{3}$ & WHO (2018) \\
\hline $\mathrm{pH}$ & 7.99 & 8 & 7.09 & 6.81 & 7.35 & 8 \\
\hline $\mathrm{EC}$ & 955 & 924 & 4560 & 2240 & 1200 & 100 \\
\hline $\mathrm{K}$ & 20 & 20 & 36 & 50 & 20.8 & 250 \\
\hline $\mathrm{Cl}$ & 136 & 144 & 880 & 228 & 152 & 200 \\
\hline $\mathrm{Na}$ & 131 & 126 & 485 & 212 & 150 & 10 \\
\hline $\mathrm{NO}_{3}$ & 8.5 & 7.8 & 38.1 & 73.8 & 61.3 & 200 \\
\hline $\mathrm{Alk}$ & 148 & 140 & 152 & 148 & 164 & 0.3 \\
\hline $\mathrm{Fe}$ & 0.08 & 0.09 & 0.07 & 0.06 & 0.05 & 0.01 \\
\hline $\mathrm{Pd}$ & 0.04 & 0.03 & 0.03 & 0.1 & 0.06 & 0.02 \\
\hline $\mathrm{Cd}$ & 0.02 & 0.01 & 0 & 0 & 0 & 0.02 \\
\hline $\mathrm{Cr}$ & 0 & 0 & 0 & 0 & 0 & 0.05 \\
\hline
\end{tabular}




\section{Sanitation}

Sewage water is not confined to the water allocated to homes and the consumption of human beings daily, but mixed with other large proportions, such as rain water and water roads with waste and dust burnt from exhaust cars and other means of transport in addition to the outputs of small factories and it contains sewage oils and grease originated from gas stations and engine oil changes, also cleaning materials rich in plant compounds such as nitrogen and phosphorus, which leads to the growth of algae and plants in places were mixed with water, all these inputs to the sewage network be loaded with large quantities of chemicals of various types and contains many heavy elements such as lead, arsenic, nickel and mercury which causes chronic diseases on human health (Tilley et al., 2014).

Most of the people in Ajdabiya city suffered from the lack of potable water and the flood of sewage water in the streets and residential buildings without paying attention to their suffering by the authorities (Fig. 2a), While they also suffer from the problem of the flood of black sewage, most of the people are transferring sewage on their own accounts, and some of them dug wells that cause serious danger to groundwater. However, these problems did not find a response from municipal council officials. The citizens in Ajdabiya city complain of the continued flood of sewage in the area near cafes, restaurants and shops that adjacent to the city's civil registry building (Fig. 2b). Moreover, the citizens explained that the problem of sewage flooding has been for a long time, indicating that this problem caused the spread of odors and the threat to public health.
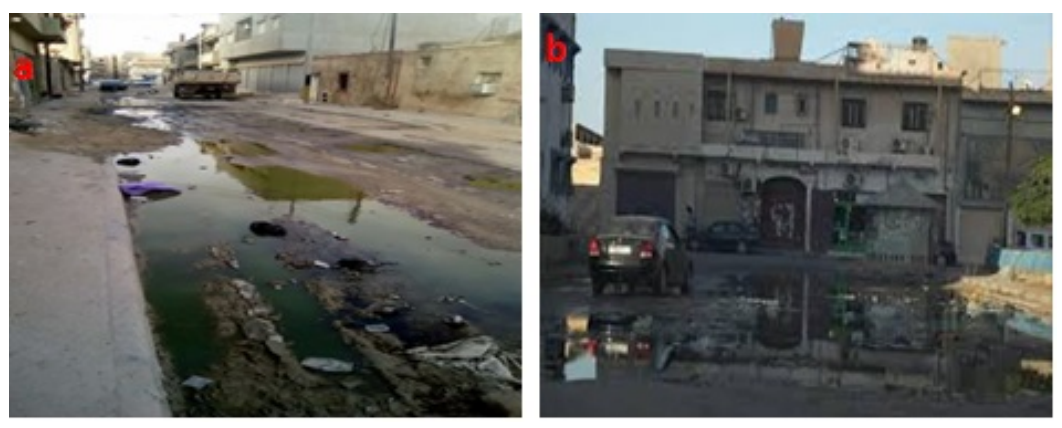

Fig.2 :(a) Flooding of sewage water in the streets for long time (b) Flooding of sewage in the area near cafes, restaurants and shops

\section{The Most Important Problems in Sanitation}

1-The sewage system is a plant or network designed since the 1980s according to the quality of pipes for the material of life that ended more than 25 years, where the infrastructure in Ajdabiya needs to be renovated, especially in the lifting station and sewage treatment network within the city (Fakhri and Fayez, 2004). 


\section{2- Lack of periodic maintenance.}

3- Most sewage water flows into the ground and sabkha lakes without treatment, which leading to contamination of groundwater.

4-Most people dig wells for sewage water without packaging with cement, which leads to contamination of groundwater, especially in suburbs.

\section{Sewage Station in Ajdabiya City}

The station is far about $7 \mathrm{~km}$ south of Ajdabiya city. It was designed to treat $15,400 \mathrm{~m}^{3}$ of sewage, but a great overlap of all types of sewage which led to the reduction of the efficiency of the sewage station (Fig. 3a). Table 2 shows the results exceeded the permissible limit according to the design capacity of the station, which leads to a large pollution, the entry of large amounts of oil and grease from the gas stations and cars wash to form a large layer on the surface of the basin, which blocks the oxygen and light on the organisms within the water, leading to fermentation (Fig. 3b), methane and hydrogen sulfide emissions, also collects a large number of harmful insects at the station.

Table 2: Specification of sewage water for a sample from Ajdabiya station (Alfakhiry and Fayez, 2004)

\begin{tabular}{|c|c|c|}
\hline Properties & Design limits & Actual Limits \\
\hline $\mathrm{pH}$ & $6.5-8.5$ & $5-9.5$ \\
\hline B. O. D & $500 \mathrm{mg} / 1$ & $800 \mathrm{mg} / 1$ \\
\hline C. O. D & $900 \mathrm{mg} / 1$ & $1400 \mathrm{mg} / 1$ \\
\hline T. S. S & $250 \mathrm{mg} / 1$ & $450 \mathrm{mg} / 1$ \\
\hline Suspended Materials & $56 \mathrm{mg} / 1$ & $80 \mathrm{mg} / 1$ \\
\hline
\end{tabular}
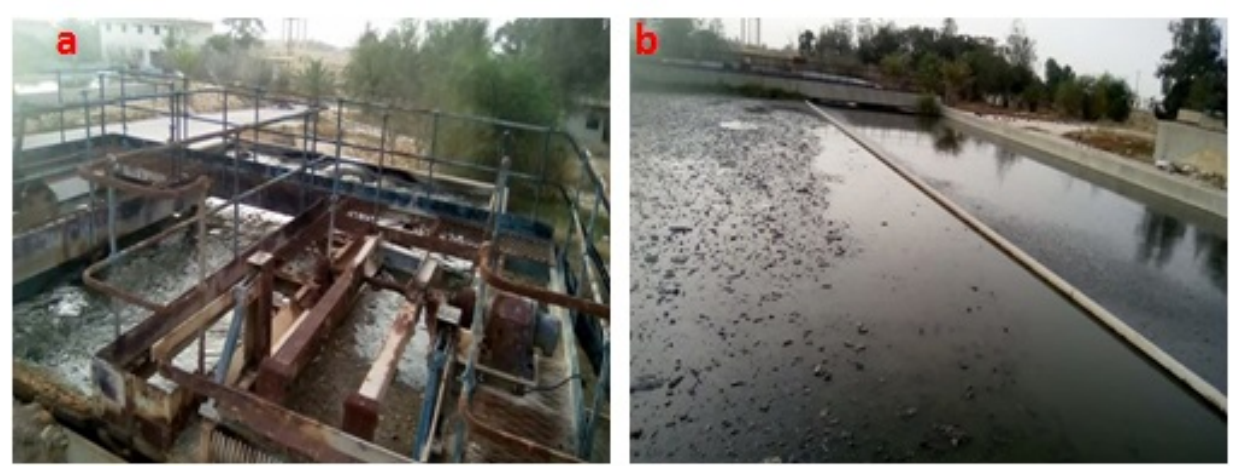

Fig.3: (a) Overlap all types of sewage water (b) Fermentation due to layer on the surface water which blocks the oxygen and light on the microorganisms

\section{CONCLUSIONS}

1- The studied water samples show the Ajdabiya reservoir needs treatment to remove the contamination before using for drinking while we do not recommend the water of the household wells for drinking or other uses due to mixed with the sewage water. 
2- Several techniques are well established and have been used in many countries for the removal of heavy metals from drinking water such as ion exchange, reverse osmosis and nano filtration.

3-All the parameters of sewage water are above the design limits which leads to damage to sanitation.

\section{RECOMMENDATIONS}

1-Ajdabiya city needs a renewal of infrastructure especially in the lifting station and sewage network within the city.

2- Groundwater wells should be isolated from sanitation.

3- Awareness of the local people on the effect of wastewater on human health.

\section{REFERENCES}

Al Fakhiry, and Fayez, A., 2004. The environmental effects of the Ajdabiya sewage station and sewage treatment, Environmental Journal, 22pp.

Al Kassah, F., Abdulhafeed, A., Al Kassah, F., Amhanaa, S., Deeh, A., and Sheikhy, S., 2017. Hydrochemical study of some groundwater wells in Ajdabiya, Libya. The Fourth Scientific Conference of Environment and Sustainable Development in the Arid and Semi- Arid Regions (ICESD): 839- 856.

Al Qawati, M., El Qaysy, M., Darwesh, N., Sibbari, M., Hamdaoui, F., Kherrati, I., El Kharrim, K., and Belghyti, I., 2018. Hydrogeochemical study of groundwater quality in the West of Sidi Allal Tazi, Gharb area, Morocco. Journal of Materials and Environmental Science, 9(1): 293-304.

Caerio, S., Costa, M.H., Ramos, T.B., Fernandes, F., Silveira, N., Coimbra, A. and Painho, M., 2005. Assessing heavy metal contamination in Sado Estuary sediment: An index analysis approach. Ecological Indicators, 5: 155-169.

Giglia, G., 1984. Geological Map of Libya. 1: 250000 Sheet NH 34-6, Ajdabiya Explanatory Booklet. Ind. Res. Cent. Tripoli, 93pp.

Shaltami, 2012. Mineral Composition and Environmental Geochemistry of the Beach Sediments along the Mediterranean Coast from Benghazi to Bin jawed, Northeast Libya Ph. D. Cairo University.

Shaltami, O.R., Fares, F.F., Errishi, H., and Bustany, I., 2017. Estimation of groundwater quality for drinking and irrigation purposes: A case study of Al Marj city, Al Jabal Al Akhdar, NE Libya. V International Congress on Subsurface Environment, Sao Paulo, Brazil, Proceeding Book, 80-96.

Tilley, E., Ulrich, L., Lüthi, C., Reymond, Ph., and Zurbrügg, C., 2014. Compendium of Sanitation Systems and Technologies (2nd Revised Edition). Swiss Federal Institute of Aquatic Science and Technology (Eawag), Duebendorf, Switzerland; ISBN 978-3-906484-57-0.

Kourgialas, N., Karatzas, P., and Koubouris, C., 2017. Hydrogeochemical study of groundwater quality in the West of Sidi Allal Tazi, Gharb area, Morocco. Journal of Environmental Management, 189: 150- 159.

EPA 822-F-18-001, Office of Water, U.S. Environmental Protection Agency Washington; 12pp.

WHO, 2011. Guidelines for drinking-water quality. 4th edition; $564 \mathrm{pp}$.

WHO, 2018. Edition of the drinking water standards and health advisories Tables. 